\title{
Terjemahan Aspek Budaya Dalam Subtitle Film Date Night
}

\author{
Mursyid Kasmir Naserly \\ AKOM BSI Jakarta \\ Email: mursyid.myk@bsi.ac.id
}

\begin{abstract}
The purpose of this study was to obtain a comprehensive picture of the cultural aspects in the movie Date Night subtitle translation. Translation is traced in terms of culture and translation. This study is a qualitative study using content analysis techniques. Object of this research is the translation subtitles on the movie Date Night, Shawn Levy's film which is in English and translated into Indonesian in the form of subtitling. The film highlights the social and cultural life in America, ranging from divorce, crime to political themes; it would not be surprised if this film had won several awards in 2010 and 2011. There are five aspects of the approach used in the research culture, including the ecological aspects, aspects of material culture, social cultural aspects, organizational aspects, customs, activities, concepts, beliefs and aspects of the habits and body language. Subtitle translation that has mixed with the cultural aspects of translation approaches and methods of translation strategies. The findings of this study as follows, aspects of culture found in the subtitle translation tends to refer to the translation of communicative strategies and make the target language as a direction for conveying information to readers. The key is the translator skills to establish an effective and concise language of the subtitle display.
\end{abstract}

Key words: cultural aspects, subtitle translation, translation, film,

\section{PENDAHULUAN}

Penerjemahan sangat penting demi proses tukar-menukar informasi dan hasil penemuan. Tanpa penerjemahan, para calon ilmuwan ataupun para ilmuwan mungkin akan ketinggalan, tidak dapat mengikuti perkembangan ilmu pengetahuan, apalagi kalau mereka kurang mampu membaca teks berbahasa asing. Itulah sebabnya, penerjemahan tidak hanya perlu dikerjakan oleh negara berkembang, bahkan negara maju pun tetap giat menerjemahkan buku. Dick Hartoko dalam Widyamartaya (1989:9) berkata, "Kebutuhan menerjemahkan buku bukanlah tanda keterbelakangan. Justru sebaliknya, tanda keterbukaan, tanda kegiatan hendak ikut serta dalam tukar-menukar informasi."

Penjelasan singkat mengenai definisi penerjemahan di atas menyimpulkan suatu konsep dasar bahwa penerjemahan harus memiliki hubungan kesepadanan antara dua teks sumber dan sasaran. Oleh karena itu, tugas utama seorang penerjemah adalah memperoleh kesepadanan ungkapan dari Bsu di dalam Bsa.

Dari sekian banyak tipe terjemahan yang berupa tulisan, baru-baru ini juga dikenal metode penerjemahan yang berupa terjemahan audiovisual, dalam hal ini terjemahan dipadukan tidak hanya dengan konjungsi tetapi juga dengan gambar di layar (bioskop, televisi, DVD atau permainan dalam komputer). (Hatim dan Munday, 2004:4). Salah satu bentuk terjemahan audiovisual yang populer saat ini adalah terjemahan subtitle.

Terjemahan subtitle sangat perlu dikembangkan mutunya karena subtitle memiliki peran dalam perkembangan film-film asing yang merambah perfilman nasional saat ini. Film Date Night salah satunya, sebagai sumber data penelitian ini, Date Night merupakan sebuah judul film yang memiliki kualitas cerita dan subtitling yang baik karena sudah diedarkan secara luas di Indonesia. Film ini bercerita tentang drama kehidupan sepasang suami istri yang hidup di pinggiran kota New York, keduanya merupakan pekerja keras namun mereka tetap memiliki quality time untuk keharmonisan rumah tangga mereka. Budaya barat sangat terasa dari awal sampai akhir film ini. Date Night adalah sebuah film karya Shawn Levy yang memakai bahasa Inggris dan diterjemahkan ke bahasa Indonesia dalam bentuk subtitling. Film ini menyoroti kehidupan sosial dan budaya di Amerika, mulai dari kasus perceraian, kriminalitas hingga tema politik, maka tak heran jika film ini sempat memenangkan beberapa penghargaan di tahun 2010 dan 2011.

Dalam hal ini penulis ingin memfokuskan diri ke dalam terjemahan subtitle. Terjemahan subtitle termasuk ke dalam salah satu prosedur penerjemahan yang dinamakan sebagai kesetaraan budaya (cultural equivalent) (Newmark, 1991:3). Budaya melibatkan nilai-nilai kehidupan dan pergaulan serta apa yang diyakini dari sebuah masyarakat. Atau dengan kata lain, budaya adalah gaya hidup manusia biasa yang menyangkut nilainilai, keyakinan, dan prasangka yang dimiliki bersama oleh sebuah masyarakat dalam wadah kebahasaan dan kelompok sosial tertentu yang membedakannya dengan kelompok yang lain. Nilainilai dan keyakinan serta prasangka budaya itu tentu saja akan terealisasikan dalam bahasa yang bersangkutan. Dengan demikian, menerjemahkan, 
disadari atau tidak, tidak akan bisa lepas dari tindakan mentransfer budaya.

Berdasarkan latar belakang yang telah dijelaskan di atas, penelitian ini difokuskan pada Penerjemahan aspek budaya dalam subtitle film Date Night dari bahasa Inggris ke dalam bahasa Indonesia. Subfokus penelitian ini adalah bentukbentuk aspek budaya yang dipergunakan dalam terjemahan subtitle, bentuk-bentuk kesepadanan, strategi-strategi penerjemahan dan penyimpanganpenyimpangan yang ditemukan dalam terjemahan subtitle yang mempengaruhi tingkat kejelasan dari bahasa sumber terhadap bahasa sasaran dalam film Date Night.

\subsection{Hakikat Penerjemahan}

Penerjemahan selama ini didefinisikan melalui berbagai cara dengan latar belakang teori dan pendekatan yang berbeda. Penerjemahan adalah upaya mengalihkan pesan dari satu bahasa ke bahasa lain. Oleh karena itu, kita tidak dapat melihat penerjemahan sebagai sekedar upaya menggantikan teks dalam satu bahasa ke bahasa lain. (Sayogie, 2008:7). Beda bahasa, maka beda pula makna dan struktur penulisannya. Perlu adanya ketelitian dalam setiap proses penerjemahan agar didapatkan makna yang tepat dan akurat. Karena proses yang pelik itulah maka para ahli pun memiliki pendapatnya sendiri-sendiri tentang penerjemahan. Nida dan Taber (1982:12) mengemukakan bahwa "Translation consists in reproducing in the receptor language the closest natural equivalent of the source language message, first in terms of meaning and secondly in terms of style." Atau dengan kata lain penerjemahan itu mencakup pada upaya mereproduksi makna (prioritas utama) dan gaya bahasa yang secara alamiah paling sepadan dengan yang terdapat dalam Bsu ke dalam Bsa.

Menurut Newmark (1988:5), penerjemahan adalah pengalihan makna suatu teks ke dalam bahasa lain sesuai dengan apa yang dimaksud oleh pengarang. "Translation is rendering the meaning of a text into another language in the way that the author intended the text."

Kedua pendapat di atas memiliki kesamaan dalam hal mereproduksi makna yang sepadan dalam penerjemahan. Namun, pendapat Newmark lebih menitikberatkan terjemahan pada maksud si pengarang dibandingkan dengan pendapat Nida dan Taber yang lebih fleksibel yaitu hanya melihatnya dari kesepadanan alamiah antara Bsu dan Bsa.

Tetapi, pernyataan Newmark (1981:7) sebelumnya itu ternyata juga Ia sempurnakan kembali di dalam bukunya yang lain, bahwa penerjemahan adalah suatu proses pengalihan pesan yang terdapat dalam teks bahasa sumber dengan padanannya di dalam bahasa sasaran. "Translation is a craft consisting in the attempt to replace a written message and / or statement in one language by the same message and / or statement in another language." Sama halnya dengan apa yang diungkapkan Catford (1965:20) yang juga mendefinisikan penerjemahan sebagai penggantian teks dalam satu bahasa (bahasa sumber) dengan teks yang ekivalen dalam bahasa lain (bahasa sasaran). "Translation is the replacement of textual material in one language (Source Language) by equivalent textual material in another language (Target Language),"

Keempat pendapat ahli di atas nampaknya hanyalah menjelaskan penerjemahan dalam bentuk umum saja, berbeda dengan apa yang dipaparkan Larson (1989:3) bahwa penerjemahan itu berarti mempelajari leksikon, struktur gramatikal, situasi komunikasi, dan konteks budaya dari teks bahasa sumber, lalu menurutnya, menganalisis teks bahasa sumber itu bertujuan untuk menemukan makna dan mengungkapkannya kembali ke makna yang sama dengan leksikon dan struktur gramatikal yang sesuai dalam bahasa sasaran dan konteks budaya. Penjelasannya sangatlah detil dan menegaskan bahwa segala macam aspek kebahasaan juga turut serta dilihat ketika proses penerjemahan itu terjadi.

Berdasarkan definisi-definisi para ahli di atas dapat disimpulkan bahwa (1) penerjemahan melibatkan dua bahasa, yaitu bahasa sumber (source language) dan bahasa sasaran (target language), (2) penerjemahan adalah upaya mengalihkan teks bahasa sumber dengan teks yang sepadan dalam bahasa sasaran, dan (3) yang diterjemahkan adalah makna sebagaimana yang dinyatakan oleh pengarang.

\section{Strategi Penerjemahan}

Strategi penerjemahan berkaitan dengan tataran lebih kecil dari suatu teks yaitu kalimat, klausa, frase, dan kata; sedangkan metode penerjemahan berkenaan dengan keseluruhan teks sebagai wacana yang utuh. (Newmark, 1988:81).

Strategi penerjemahan yang dikemukakan oleh Newmark menyerupai proses penerjemahan dalam metode penerjemahan literal (harfiah), yang dilakukan pada tataran klausa atau kalimat, di antaranya adalah hal-hal berikut:

a. Transposition (transposisi) yaitu mengubah struktur kalimat agar dapat memperoleh terjemahan yang benar. Pengubahan ini dilakukan jika terdapat perbedaan antara struktur bahasa sumber dan bahasa sasaran yang wajar. Pengubahan ini bisa bermacam-macam, bisa pengubahan bentuk tunggal ke bentuk jamak, posisi kata sifat, sampai pengubahan struktur kalimat secara keseluruhan. (Newmark, 1988:85). Transposisi bisa dipandang sebagai suatu keharusan atau sebagai pilihan. Transposisi bisa menjadi keharusan, apabila tanpa strategi ini makna bahasa sumber tidak tersampaikan. Transposisi menjadi pilihan apabila transposisi dilakukan karena alasan gaya bahasa saja. 
Artinya, tanpa transposisi pun makna bahasa sumber bisa diterima oleh pembaca teks bahasa sasaran.

Contoh: trade secrets and confidential $\rightarrow$ rahasia dagang (Hoed, 2006:12).

b. Modulation (modulasi) yaitu memberikan padanan yang secara semantik berbeda artinya atau cakupan maknanya, tetapi dalam konteks yang bersangkutan memberikan pesan yang sama.

Contoh: BSu: The laws of Germany govern this agreement.

BSa: Perjanjian ini diatur oleh hukum Jerman. (Hoed, 2006:12)

c. Descriptive equivalent (penerjemahan deskriptif), yaitu membuat uraian yang berisi makna kata yang bersangkutan, karena tidak menemukan padanan kata bahasa sumber, baik karena tidak tahu maupun karena tidak ada atau belum ada dalam bahasa sasaran. Contoh: Licensed software $\rightarrow$ perangkat lunak yang dilisensikan (Hoed, 2006:13).

d. Cultural equivalent (padanan budaya), yaitu menerjemahkan dengan memberikan padanan berupa unsur kebudayaan yang ada dalam bahasa sasaran. Yang harus diperhatikan di sini adalah kata khas suatu bahasa itu artinya juga khas budaya bahasa tersebut. Oleh karena suatu budaya tidak pernah sama, maka kemungkinan besar strategi ini tidak bisa menjaga ketepatan makna. Walaupun begitu untuk teks yang bersifat umum, pengumuman atau propaganda, strategi ini bisa digunakan karena pembaca teks bahasa sasaran tidak begitu peduli akan budaya bahasa sumber. (Newmark, 1988:82-83). Contoh: "A" level exam $\rightarrow$ ujian SPMB (Hoed, 2006: 14).

e. Transference (pemindahan kata) merupakan salah satu prosedur penerjemahan yang memindahkan kata dari bahasa sumber ke dalam bahasa sasaran. (Newmark, 1988:81). Ini berarti bahwa tidak semua bagian dari kalimat bahasa sumber diterjemahkan ke dalam bahasa sasaran. Kata atau frasa yang tidak diterjemahkan itu dapat berupa aspek budaya pada bahasa sumber yang sulit dicari padanan katanya dalam bahasa sasaran, atau dikarenakan penerjemah ingin mempertahankan gaya bahasa dari karya asli pada bahasa sasaran.

Contoh: mall $\rightarrow$ mall

f. Naturalization yaitu membuat kata baru yang diambil dari bahasa sumber untuk disesuaikan dengan bunyi dan ejaan bahasa sasaran. (Newmark, 1988:82)

Contoh: escalator $\rightarrow$ eskalator

g. Adaptation (adaptasi) digunakan untuk mencari padanan kultural antara dua situasi tertentu. Beberapa ungkapan kultural yang konsepnya tidak sama dengan bahasa sumber dan bahasa sasaran memerlukan adaptasi. Hal ini dilakukan untuk mempermudah pembaca bahasa sasaran dalam memahami teks.

Contoh : Dear Sir $\rightarrow$ Yang Terhormat

h. Addition (penambahan kata) digunakan sebagai penjelasan lebih lanjut untuk kata yang berhubungan dengan aspek budaya bahasa sumber yang tidak dapat diterjemahkan begitu saja ke dalam bahasa sasaran. Dalam hal ini, penerjemah menambahkan penjelasan yang dirasa perlu pada terjemahannya untuk mempermudah pembaca memahami isi teks. Informasi tambahan ini dapat diletakkan langsung pada teks, pada catatan kaki (footnote), atau pada bagian akhir teks (glossary).

\subsection{Klasifikasi Aspek Budaya dalam Penerjemahan}

Menyadari pentingnya pemahaman lintas budaya dalam penerjemahan, berbagai ahli bidang penerjemahan telah berupaya meneliti perbedaanperbedaan kultural diantara berbagai bahasa. Hasilhasil penelitian itu sangat membantu pengembangan prosedur-prosedur penerjemahan dalam rangka mengatasi kesulitan-kesulitan yang timbul akibat perbedaan-perbedaan budaya. Salah satu konsep yang dilandaskan pada hasil-hasil penelitian tersebut adalah konsep 'cultural words' yang diajukan Newmark. Konsep ini mengungkapkan bahwa dalam sebuah teks seluruh aspek budaya diungkapkan dalam 'cultural words' tersebut. Aspek-aspek tersebut dapat diterjemahkan dalam berbagai cara sesuai dengan perannya dalam teks dan tujuan penerjemahan. Untuk mempermudah pemahaman, aspek-aspek tersebut dibagi ke dalam kategori dan sub-kategori seperti terlihat pada Tabel 1.

Tabel 1: Lima Kategori Aspek Budaya Menurut Newmark (1988:95-102)

\begin{tabular}{|c|c|c|}
\hline No & Kategori & $\begin{array}{l}\text { Sub-Kategori / } \\
\text { Elemen }\end{array}$ \\
\hline 1. & Ekologi & $\begin{array}{l}\text { flora, fauna, gunung, } \\
\text { angin, daratan, dll. }\end{array}$ \\
\hline 2. & $\begin{array}{l}\text { Kebudayaan } \\
\text { Material }\end{array}$ & $\begin{array}{l}\text { makanan, pakaian, } \\
\text { rumah, kota, sarana } \\
\text { transportasi }\end{array}$ \\
\hline 3. & Kebudayaan Sosial & pekerjaan, liburan \\
\hline 4. & $\begin{array}{l}\text { Organisasi, adat- } \\
\text { istiadat, Aktivitas, } \\
\text { Konsep-konsep, } \\
\text { kepercayaan }\end{array}$ & $\begin{array}{l}\text { Sistem } \\
\text { pemerintahan, } \\
\text { politik, nilai-nilai } \\
\text { artistik, acara-acara } \\
\text { keagamaan. }\end{array}$ \\
\hline 5. & $\begin{array}{l}\text { Kebiasaan dan } \\
\text { bahasa tubuh }\end{array}$ & $\begin{array}{l}\text { Gerak-gerik tubuh, } \\
\text { kebiasaan }\end{array}$ \\
\hline
\end{tabular}

\section{Proses subtitling}

Subtitling adalah proses transfer informasi dari bahasa sumber (SL) ke bahasa target (TL) dan rekonstruksi informasi dalam TL. Ketika struktur SL 
dan TL memiliki pola kalimat yang sama, atau bahasa sumber yang pendek, dengan jeda sering, subtitling bisa sehalus mungkin menginterpretasikannya berturut-turut. Perbedaannya adalah bahwa output dalam subtitling ditulis sedangkan dalam penafsiran berturut-turut secara lisan.

\section{SL SPEECH TL SPEECH}

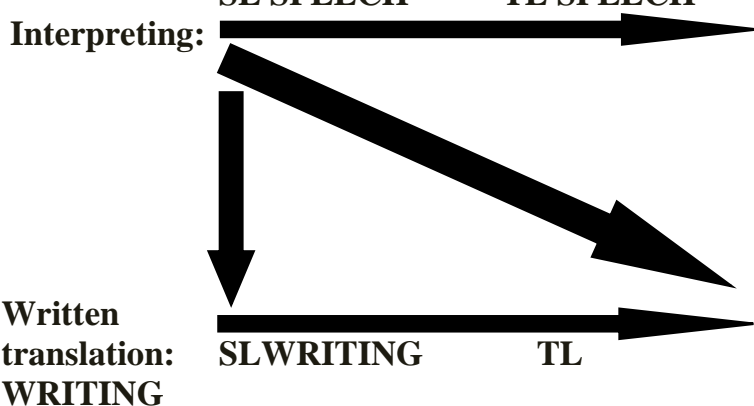

\section{Gambar 1. Penerjemahan Subtitle}

Namun, ketika perbedaan dalam struktur antara dua bahasa muncul, subtitler harus mundur dan merevisi terus-menerus. Selama proses subtitling, berdasarkan gambar-gambar di layar, soundtrack dari karakter, ucapan para karakter, transkripsi, atau informasi lainnya dalam bahasa sumber, mental subtitler dipatahkan dari sumber bahasa ke dalam unit-unit pemikiran, mentransfer mereka satu per satu ke dalam bahasa target sesederhana mungkin dan sesuai dengan ekspresi sehari-hari yang tepat dalam hal penggunaan dan gaya, dan menggunakan TL sebagai alokasi, frasa, dan idiom. Setelah itu, subtitler yang merevisi target bahasa dan mencoba untuk memastikan bahwa subtitle itu sesuai dengan struktur sintaksis, dan ekspresi yang sederhana, lancar, akrab dengan situasi sehari-hari, dan up-todate, tanpa meninggalkan jejak terjemahan. Akhirnya, subtitler mengikuti aspek-aspek lain dari norma-norma linguistik. Bagian-bagian dari seluruh proses kadang-kadang berjalan bersamaan, dengan frekuensi backtracking. Seorang subtitler berpengalaman dapat mengurasi resiko menerjemahkan dengan revisi dan backtracking. (Chen, 2004:122).

\section{METODOLOGI PENELITIAN}

Penelitian ini menggunakan metode analisis isi yang bersifat deskriptif untuk mendapatkan pendalaman empat hal utama: pertama bentukbentuk aspek budaya yang dipergunakan dalam terjemahan subtitle dari bahasa Inggris ke dalam bahasa Indonesia dalam film Date Night, kedua bentuk-bentuk kesepadanan budaya yang dipergunakan dalam terjemahan subtitle dari bahasa Inggris ke dalam bahasa Indonesia dalam film Date Night, ketiga memahami strategi-strategi penerjemahan yang dipergunakan untuk menerjemahkan subtitle film Date Night dari bahasa Inggris ke dalam bahasa Indonesia, dan keempat mengetahui penyimpanganpenyimpangan di dalam terjemahan subtitle yang mempengaruhi tingkat kejelasan dari bahasa sumber terhadap bahasa sasaran dalam film Date Night. Dengan menggunakan pendekatan kualitatif dan metode analisis isi, penelitian ini diharapkan mampu memaparkan unsur kesepadanan budaya dari teks terjemahan subtitle dari bahasa Inggris ke dalam bahasa Indonesia. Setiap analisis yang dilakukan, diobservsi melalui data dan studi kepustakaan sehingga metode deskriptif yang dilakukan melalui kajian teks dapat terfokus pada tujuan penelitian.

\section{HASIL DAN PEMBAHASAN}

\section{A. Pembahasan tentang jenis aspek budaya yang ditemukan dalam film Date Night dan prosedur penerjemahan yang digunakan}

Berdasarkan data yang diperoleh, terlihat bahwa aspek kata budaya yang banyak digunakan oleh penerjemah dalam menerjemahkan subtitle bahasa Inggris ke dalam bahasa Indonesia adalah prosedur penerjemahan adaptasi, naturalisasi, tansference atau pemindahan kata dan padanan budaya. Berikut adalah contoh pembahasan subtitle dan prosedur penerjemahannya. Aspek budaya yang $\begin{gathered}\text { diterjemahkan } \\ \text { menggunakan prosedur }\end{gathered}$
penemahan adaptasi.

TSu : - I love you!

TSa : - Aku sayang Ibu!

Pembahasan : Terjemahan di atas merupakan salah satu bentuk ungkapan yang diucapkan oleh Charlotte saat ia membangunkan Ibunya Claire Foster di pagi hari. Setelah ia membangunkan Ibunya, Ia lalu mengatakan "I love you!” kalimat tersebut merupakan ungkapan yang ditujukan untuk Ibunya. Penerjemah menangkap pesan tersebut sebagai ungkapan kasih sayang seorang anak kepada Ibunya dengan terjemahan “Aku sayang Ibu!”. Arti Love dalam kamus adalah cinta, asmara, kecintaan, kasih dan kasih sayang. Melihat makna tersebut maka ungkapan "Aku sayang Ibu!” dalam terjemahan subtitle di atas merupakan wujud aspek budaya yang mengarah pada konsep-konsep kekerabatan. Hal ini sangat perlu digunakan dalam penerjemahan agar terjemahan yang dihasilkan dapat menyalurkan pemahaman lintas budaya dalam bahasa yang berbeda.

Strategi penerjemahan subtitle yang diterapkan adalah adaptasi. Strategi tersebut terlihat dalam bahasa sasaran bahwa kata "You" diterjemahkan menjadi kata "Ibu". Hal ini menunjukkan bahwa terdapat ungkapan kultural yang konsepnya tidak sama dengan 
bahasa sumber. Oleh karena itu, bahasa sasaran memerlukan adaptasi akan hal itu. Pada budaya barat mereka tidak mengenal adanya sistem kekerabatan yang erat serupa budaya Indonesia. Prosedur penerjemahan ini juga digunakan untuk menerjemahkan 37 data lain yang termasuk ke dalam kelompok ini.

b. Aspek budaya yang diterjemahkan menggunakan prosedur penerjemahan naturalisasi.

TSu : give them a bath and get them into their pajamas,

TSa : ...memandikan mereka dan memakaikan piyama...

Pembahasan : Ungkapan di atas diucapkan oleh Claire Foster yang sedang menjelaskan kegiatannya sepanjang hari kepada suaminya Phil Foster. Calire setiap hari melakukan kegiatan layaknya ibu rumah tangga lainnya dengan mengungkapkan "give them a bath and get them into their pajamas," Penerjemah menerjemahkan pesan tersebut dengan terjemahan “...memandikan mereka dan memakaikan piyama...” dalam terjemahan subtitle di atas merupakan wujud aspek budaya yang mengacu pada budaya material.

Strategi penerjemahan subtitle yang diterapkan adalah naturalisasi. Strategi tersebut terlihat dalam bahasa sasaran bahwa kata "pajamas" diterjemahkan menjadi kata “piyama...”. Strategi tersebut dilakukan dengan padanan kultural yang terdapat dalam bahasa sasaran. Prosedur penerjemahan ini juga digunakan untuk menerjemahkan 3 data lain yang termasuk ke dalam kelompok ini.

c. Aspek budaya yang diterjemahkan menggunakan prosedur penerjemahan transference atau pemindahan kata

TSu : drinking a Diet Sprite, by myself.

TSa : $\quad$ Meminum Diet Sprite sendiri.

Pembahasan : Terjemahan di atas merupakan bentuk pernyataan yang diucapkan oleh Claire Foster kepada suaminya saat ia menjelaskan impiannya jika sedang sendiri di kamar hotel dengan meminum minuman favoritnya dengan mengatakan "drinking a Diet Sprite, by myself.”. Penerjemah menerjemahkan pesan tersebut dengan terjemahan "Meminum Diet Sprite sendiri.”. Melihat pernyataan "Meminum Diet Sprite sendiri." dalam terjemahan subtitle di atas merupakan wujud aspek budaya yang cukup menjelaskan bahwa "Diet Sprite” adalah nama sebuah minuman soda yang populer di Amerika serikat sebagai wujud kata budaya material.
Strategi penerjemahan subtitle yang diterapkan adalah transference (pemindahan kata. Strategi tersebut terlihat dalam bahasa sasaran bahwa kata "Diet Sprite" diterjemahkan tetap menjadi kata "Diet Sprite". Strategi tersebut adalah pemindahan kata dari bahasa sumber ke dalam bahasa sasaran, hal ini berarti bahwa tidak semua bagian dari kalimat bahasa sumber bisa diterjemahkan ke dalam bahasa sasaran. Karena kata atau frasa yang tidak diterjemahkan itu merupakan aspek budaya pada bahasa sumber yang sulit dicari padanan katanya dalam bahasa sasaran dan di satu sisi penerjemah juga ingin mempertahankan unsur budaya dari bahasa sumber pada bahasa sasaran.

Hal ini menunjukkan bahwa terdapat ungkapan yang konsepnya tidak sama dengan bahasa sumber. Oleh karena itu, bahasa sasaran memerlukan strategi Transference (pemindahan kata) akan hal itu. Prosedur penerjemahan ini juga digunakan untuk menerjemahkan 10 data lain yang termasuk ke dalam kelompok ini.

d. Aspek budaya yang diterjemahkan menggunakan prosedur penerjemahan padanan budaya.

TSu : Claire, they have our IDs.

TSa : Claire, mereka memiliki KTP kita.

Pembahasan : Terjemahan di atas merupakan ungkapan yang diucapkan oleh Phil Foster kepada istrinya Claire Foster yang bergegas ingin pulang, namun Phil berhasil meredakan emosi Claire tersebut dengan menjelaskan bahwa mereka tak akan bisa bebas dari polisi preman yang sedang mengejar mereka, sebab polisi gadungan tersebut telah memiliki kartu identitas mereka, dan Phil membujuk Claire agar ia tidak bersikeras lagi untuk pulang, dengan mengatakan "Claire, they have our IDs. They know where we live.” Penerjemah menerjemahkan pesan tersebut dengan terjemahan "Claire, mereka memiliki KTP kita. Mereka tahu di mana kita tinggal”. Melihat ungkapan "mereka memiliki KTP kita” Dalam terjemahan subtitle di atas merupakan wujud kata budaya material.

Karena kalimat "they have our IDs" pada bahasa sasaran memiliki perbedaan makna, maka inisiatif penerjemah untuk menyesuaikannya dengan konteks "mereka memiliki KTP kita” dirasa sangatlah tepat untuk menerjemahkan ungkapan tersebut.

Strategi penerjemahan subtitle yang diterapkan adalah padanan budaya. Strategi tersebut terlihat dalam bahasa sasaran bahwa ungkapan "they have our IDs" diterjemahkan menjadi “mereka memiliki KTP kita”. Strategi tersebut memberikan padanan berupa unsur 
kebudayaan yang ada dalam bahasa sasaran. Dalam hal identitas pada bahasa sasaran lebih akrab menggunakan istilah "KTP (Kartu Tanda Penduduk)" dibandingkan "ID (Identity/Identitas)”. Hal ini menunjukkan kekhasan suatu bahasa. Karena suatu budaya tidak pernah sama, maka kemungkinan besar strategi ini tidak bisa menjaga ketepatan makna. Walaupun begitu untuk teks yang bersifat umum, pengumuman atau propaganda, strategi ini bisa digunakan karena pembaca teks bahasa sasaran tidak begitu peduli akan budaya bahasa sumber. Hal ini menunjukkan bahwa terdapat ungkapan yang konsepnya tidak sama dengan bahasa sumber. Oleh karena itu, bahasa sasaran memerlukan strategi padanan budaya akan hal itu. Prosedur penerjemahan ini juga digunakan untuk menerjemahkan 16 data lain yang termasuk ke dalam kelompok ini.

\section{B. Pembahasan Strategi Penerjemahan Dalam Subtitle Date Night}

Berdasarkan data yang diperoleh, terlihat bahwa prosedur penerjemahan yang paling banyak digunakan oleh penerjemah dalam menerjemahkan subtitle bahasa Inggris ke dalam bahasa Indonesia adalah prosedur penerjemahan yaitu 214 strategi modulasi, 68 reduksi atau pengurangan dan 23 amplifikasi atau penambahan. Berikut adalah contoh pembahasan subtitle dan prosedur penerjemahannya.

a. Subtitle yang diterjemahkan menggunakan prosedur penerjemahan reduksi atau pengurangan.

TSu : Best fucking decision I ever made.

TSa : Keputusan terbaik yang pernah aku buat.

Pembahasan : Terjemahan di atas merupakan salah satu bentuk pernyataan yang diucapkan oleh Haley salah satu teman dari Claire Foster yang sedang bercerita mengenai kondisi rumah tangganya. Haley menceritakan betapa hancurnya rumah tangganya karena tidak pernah adanya kebahagiaan hingga Ia pun berkata perceraian adalah keputusan yang terbaik dengan ungkapan "Best fucking decision I ever made” Melihat pernyataan itu penerjemah pun menerjemahkan pernyataan tersebut dengan "Keputusan terbaik yang pernah aku buat”.

Strategi penerjemahan subtitle yang diterapkan adalah reduksi. Strategi tersebut terlihat dalam bahasa sasaran bahwa terdapat penghilangan kata "fucking" dalam kalimat "Best fucking decision I ever made" dengan terjemahannya "Keputusan terbaik yang pernah aku buat”. Hal tersebut perlu dilakukan sebab pada bahasa sasaran tidak mengenal budaya ungkapan kasar seperti halnya yang diungkapkan dalam bahasa sumber. Sehingga penerjemah mengambil inisiatif untuk menghilangkan terjemahan kata "fucking" dalam terjemahannya. Strategi tersebut menegaskan bahwa perlu adanya pengurangan informasi teks bahasa sumber ke dalam bahasa sasaran agar cakupan makna pada kedua konteks Bsu dan Bsa dapat tersampaikan pesan yang sama.

Hal ini menunjukkan bahwa terdapat ungkapan yang konsepnya tidak sama dengan bahasa sumber. Oleh karena itu, bahasa sasaran memerlukan strategi reduksi akan hal itu. Prosedur penerjemahan ini juga digunakan untuk menerjemahkan 67 data lain yang termasuk ke dalam kelompok ini.

b. Subtitle yang diterjemahkan menggunakan prosedur penerjemahan modulasi.

TSu: Hey. Just gonna catch the sports.

TSa : Aku cuma mau nonton tayangan olahraga.

Pembahasan : Terjemahan di atas merupakan salah satu bentuk ungkapan yang diucapkan oleh Phil Foster kepada istrinya Claire Foster. Istrinya tersebut mengajaknya untuk beranjak ke tempat tidur saat Phil sedang menonton televisi seusai mereka pulang dari restoran malam itu. Lalu Phil menolak ajakan itu dengan ucapan "Hey. Just gonna catch the sports.” Penerjemah menangkap pesan tersebut sebagai respon spontan Phil terhadap ajakan istrinya tersebut dengan terjemahan "Aku cuma mau nonton tayangan olahraga.”. Karena kalimat "Hey. Just gonna catch the sports." pada bahasa sasaran memiliki perbedaan makna, maka inisiatif penerjemah untuk memadankannya secara semantik dengan konteks "Aku cuma mau nonton tayangan olahraga.” dirasa sangatlah tepat untuk menerjemahkan ungkapan tersebut.

Kesepadanan yang digunakan pada bahasa target adalah komunikatif. Itu disebabkan karena metode komunikatif lebih berorientasi kepada bahasa sasaran. Ungkapan "Hey. Just gonna catch the sports." diterjemahkan menjadi "Aku cuma mau nonton tayangan olahraga.”.

Strategi penerjemahan subtitle yang diterapkan adalah modulasi. Strategi tersebut terlihat dalam bahasa sasaran bahwa ungkapan "Hey. Just gonna catch the sports." diterjemahkan menjadi "Aku cuma mau nonton tayangan olahraga.”. Strategi tersebut memberikan padanan yang secara semantik atau cakupan maknanya berbeda, tetapi dalam 
konteks yang bersangkutan memberikan pesan yang sama.

Hal ini menunjukkan bahwa terdapat ungkapan yang konsepnya tidak sama dengan bahasa sumber. Oleh karena itu, bahasa sasaran memerlukan strategi modulasi akan hal itu. Prosedur penerjemahan ini juga digunakan untuk menerjemahkan 213 data lain yang termasuk ke dalam kelompok ini.

c. Subtitle yang diterjemahkan menggunakan prosedur penerjemahan amplifikasi atau penambahan.

TSu : 00:18:23,936 --> 00:18:26,354 and I only have a 20,

TSa : $\quad 00: 18: 23,936$--> 00:18:26,354 dan aku hanya punya uang 20 dolar...

Pembahasan : Terjemahan di atas merupakan salah satu bentuk pernyataan yang diucapkan oleh Phil Foster kepada dua orang yang Ia anggap sebagai penipu, sebab di perkotaan sangat umum orang menggunakan alasan atau karangan cerita fiktif sebagai alasan meminta uang kepada orang yang ditemuinya di jalan. Phil Foster yakin bahwa orang yang menemuinya adalah penipu yang sedang berusaha untuk meminta uang darinya. Awalnya menolak, namun, Phil merasa kasihan kepada orang tersebut dan tetap memberikan uang kepadanya dengan mengatakan "And I only have a 20”, Ungkapan tersebut meyakinkan bahwa meskipun orang tersebut meminta hanya 5 dolar, namun Phil berbaik hati dengan memberikan mereka sebanyak 20 dolar. Melihat pernyantaan itu, penerjemah pun menerjemahkan pernyataan tersebut dengan "Dan aku hanya punya uang 20 dolar...”. Dalam terjemahan subtitle di atas merupakan wujud aspek kata budaya material.

Strategi penerjemahan subtitle yang diterapkan adalah amplifikasi. Strategi tersebut terlihat dalam bahasa sasaran bahwa terdapat kata tambahan "dolar” dalam kalimat "Dan aku hanya punya uang 20 dolar...”. hal tersebut dilakukan oleh penerjemah untuk menekankan ungkapan dari bahasa sumber "And I only have a 20,”. Strategi tersebut menegaskan bahwa perlu adanya penyertaan detail yang tidak tercantum dalam bahasa sumber, dalam bentuk informasi maupun parafrase eksplisit agar cakupan makna pada kedua konteks Bsu dan Bsa dapat tersampaikan pesan yang sama. Hal ini menunjukkan bahwa terdapat ungkapan yang konsepnya tidak sama dengan bahasa sumber. Oleh karena itu, bahasa sasaran memerlukan strategi Amplifikasi akan hal itu. Prosedur penerjemahan ini juga digunakan untuk menerjemahkan 22 data lain yang termasuk ke dalam kelompok ini.

\section{Pembahasan Penyimpangan Penerjemahan Dalam Subtitle Date Night}

a. Penyimpangan penerjemahan yang disebabkan oleh kata, frase, atau kalimat yang tidak diterjemahkan.

BSu : Katy, I don't have time to talk right now. I'll pay you double to stay.

BSa : Katy, aku tak punya waktu. Akan kugandakan bayaranmu jika menginap.

Pembahasan : Terjemahan di atas merupakan salah satu bentuk penyimpangan yang penulis temukan di dalam subtitle film Date Night. Ungkapan yang diucapkan oleh Phil Foster kepada pengasuh anaknya tersebut terjadi lewat telepon, potongan percakapan di atas menegaskan bahwa saat itu Ia sedang dalam masalah besar, jadi Phil harus memaksa pengasuh anaknya, Katy, untuk mengajak anak-anaknya untuk menginap dirumahnya, dengan mengatakan "Katy, I don't have time to talk right now. I'll pay you double to stay." Melihat pernyantaan itu, penerjemah pun menerjemahkan pernyataan tersebut dengan "Katy, aku tak punya waktu. Akan kugandakan bayaranmu jika menginap.”. Dilihat dari keutuhan makna, maka penggalan percakapan tersebut sebenarnya sudah dapat dipahami dengan jelas, oleh karena itu penerjemah menghilangkan salah satu frase yang menunjukkan keterangan waktu yaitu "to talk right now".

Namun, Jika dilihat dari sisi penerjemahan profesional, maka terjemahan penggalan percakapan tersebut sudah menyimpang keutuhan teks sumber, sebab penerjemah dengan sengaja tidak menterjemahkan frase "to talk right now" sebagai penunjuk waktu dalam penggalan tersebut. Tetapi karena penerjemahan ini ditujukan untuk subtitle, maka penerapan pola ringkas dan jelas dalam sebuah tampilan subtitle nampaknya menjadi acuan si penerjemah untuk kasus tersebut, sehingga hal ini terjadi dalam proses penerjemahannya. Penyimpangan penerjemahan ini juga penulis temukan di 29 data lain yang termasuk ke dalam kelompok ini.

b. Penyimpangan penerjemahan yang disebabkan karena Perubahan sudut pandang.

BSu : We have to get near people immediately.

BSa : Kita harus dekati mereka secepatnya.

Pembahasan : Terjemahan di atas merupakan salah satu bentuk penyimpangan perubahan sudut pandang yang penulis temukan di dalam 
subtitle film Date Night. Ungkapan yang diucapkan oleh Claire Foster kepada suaminya Phil Foster ketika mereka disandera oleh dua orang polisi bayaran di rumah perahu di Central Park itu mengandung suatu kejanggalan dari segi makna jika disesuaikan dengan makna yang terkandung di dalam bahasa sumber. Saat itu Calire mempunyai gagasan kepada suaminya Phil bahwa mereka harus mencari pertolongan segera ke orangorang terdekat di taman yang sunyi tersebut dengan mengatakan "We have to get near people immediately”. Perubahan sudut pandang terjadi ketika penulis memaknainya dengan terjemahan "Kita harus dekati mereka secepatnya”. Penulis menyadari bahwa hal tersebut adalah kekhilafan penerjemah ketika menerjemahkan subtitle, mengingat data yang banyak dan harus di kejar deadline, sehingga hal ini terjadi dalam proses penerjemahannya. Penyimpangan penerjemahan ini juga penulis temukan di 5 data lain yang termasuk ke dalam kelompok ini.

\section{c. Penyimpangan penerjemahan yang disebabkan karena Kesalahan kesepadanan leksikal.}

BSu : $\quad$ industrial intel, dealing with rogue governments,

BSa : ...informasi industrial, berurusan dengan pemerintahan kotor...

Pembahasan : Terjemahan di atas merupakan salah satu bentuk penyimpangan kesepadanan leksikal yang penulis temukan di dalam subtitle film Date Night. Ungkapan itu adalan ucapan Holbrooke kepada Claire dan Phil Foster. Ia menjelaskan bahwa pekerjaannya cukup berbahaya dan sangat erat hubungannya dengan kasus-kasus penggelapan melalui ungkapan "industrial intel, dealing with rogue governments," Melihat pernyataan itu, penerjemah pun menerjemahkan pernyataan tersebut dengan “...informasi industrial, berurusan dengan pemerintahan kotor...”. Dilihat dari keutuhan makna, maka penggalan percakapan tersebut sebenarnya sudah dapat dipahami, tapi untuk terjemahan frase “infomasi industrial” nampaknya penerjemah belum bisa memadankannya dengan bahasa sasaran sebab makna tersebut terlihat rancu dan susah untuk dicerna maksudnya. Hal ini akan membingungkan penonton yang membaca frase subtitle tersebut. Nampaknya penerjemah terlalu terburu-buru untuk memadankannya sehingga hal ini terjadi dalam proses penerjemahannya. Penyimpangan penerjemahan ini juga penulis temukan di 6 data lain yang termasuk ke dalam kelompok ini.

\section{KESIMPULAN}

Berdasarkan analisis aspek budaya dalam terjemahan subtitle maka dapat disimpulkan sebagai berikut.

1. Aspek budaya dalam terjemahan subtitle dengan sudut pandang teori penerjemahan menuntun penulis untuk menemukan beberapa aspek budaya di dalam terjemahannya. Di dalam terjemahan subtitle ditemukan aspek budaya (1) kebudayaan Material, (2) kebudayaan Sosial, (3) organisasi, adat istiadat, aktivitas, konsep-konsep, kepercayaan dan (4) kebiasaan dan bahasa tubuh.

2. Bentuk kesepadanan komunikatif lebih banyak digunakan daripada kesepadanan semantis dalam terjemahan subtitle.

3. Mengenai strategi penerjemahan subtitle, ada tujuh jenis strategi yang ditemukan dalam terjemahan subtitle film Date Night tersebut yaitu strategi adaptasi, padanan budaya, modulasi, reduksi atau pengurangan, amplifikasi atau penambahan, transference atau pemidahan kata, dan naturalisasi. Kesemuanya tersebut dianggap efektif untuk menerjemahkan subtitle menjadi bahasa yang efektif dan ringkas dalam tampilan subtitle.

4. Dari penelitian ini pun di dapat beberapa penyimpangan yang menyebabkan ketidaksepadanan, bisa dikelompokkan menjadi beberapa kelompok yaitu penyimpangan yang disebabkan oleh adanya kata-kata, frase atau kalimat yang tidak diterjemahkan, kesalahan kesepadanan gramatikal dan leksikal, adanya perubahan sudut pandang yang berbeda dengan bahasa sumber.

\section{REFERENSI}

Barnwell, Katharine. Introduction to Semantics and Translation. Horsley Green: Summer Institute of Linguistics, 1980.

Catford, J. C. A Linguistic Theory of Translation. London: Oxford University Press, 1965.

Chen, Sheng-Jie, "Linguistic Dimensions of Subtitling. Perspectice from Taiwan" in Meta : Translators’ Journal, vol 49. 2004

Emzir, Metodologi Penelitian Kualitatif Analisis Data. Jakarta: Rajawali Pers, 2010.

Hatim, Basil dan Ian Mason, The Translator as Communicator. London: Routledge, 1997.

Hoed, Benny. Penerjemahan dan Kebudayaan. Jakarta: Pustaka Jaya, 2006.

Larson, Mildred L. Penerjemahan Berdasar Makna: Pedoman untuk Pemadanan Antarbahasa. Penerjemah: Kencanawati Taniran. Jakarta: Penerbit Arcan, 1989.

Machali, Rochayah. Pedoman bagi Penerjemahan. Bandung: Kaifa, 2009.

Newmark, Peter. Approaches to Translation. Oxford: Pergamon Press, 1981.

Newmark, Peter. A Text Book of Translation. London: Prentice Hall, 1988.

Nida, E.A and Charles R. Taber. The Theory and Practice of Translation. Leiden: E. J. 
Brill, 1982.

Nord, C. Translating as a Purposeful Activity: Functional Approaches Explained. Manchester, UK: St. Jerome Publishing, 1997.

O'Connell, Eithne. Screen Translation in A Companion to Translation Studies. Clevedon: Multilingual Matters LTD, 2007.

Sayogie, Frans. Penerjemahan Bahasa Inggris ke dalam Bahasa Indonesia. Jakarta: Lembaga Penelitian UIN Syarif Hidayatullah, 2008.

Titscher, Stefan et al. Metode Analisis Teks dan Wacana. Terjemahan (Gozali dkk) Yogyakarta: Pustaka Pelajar, 2009.

Widyamartaya, A. Seni Menerjemahkan. Yogyakarta: Kanisius, 1989.

Website :

http://www.movietei.com/celeb_detail.php?idx=552

\&cel=Shawn\%20Levy diakses pada 15 April 2012.

Lucia Molina dan Amparo Hurtado Albir,

Translation Techniques Revisited: A

Dynamic and Functionalist Approach

(Meta, XLVII,4), hlm. 498-512.

http://www.erudit.org/revue/meta/2002/ v47/n4/008033ar.pdf diakses pada 27

April 2012. 